\title{
Increased Risk of Freeze Damage in Woody Perennials VIS-À-VIS Climate Change: Importance of Deacclimation and Dormancy Response
}

\author{
Rajeev Arora ${ }^{1 *}$ and Kari Taulavuori ${ }^{2}$ \\ ${ }^{1}$ Department of Horticulture, lowa State University, Ames, IA, USA, ${ }^{2}$ Department of Biology, University of Oulu, Oulu, Finland
}

Keywords: winter hardiness, freezing tolerance, deacclimation, dormancy, climate change, spring phenology, chilling brequirement, heat-units

\section{OPEN ACCESS}

Edited by:

Urs Feller,

University of Bern, Switzerland

Reviewed by:

Gary Coleman,

University of Maryland, USA

Dominique Job,

Centre National de la Recherche

Scientifique, France

*Correspondence:

Rajeev Arora

rarora@iastate.edu

Specialty section:

This article was submitted to Agroecology and Land Use Systems,

a section of the journal

Frontiers in Environmental Science

Received: 22 April 2016 Accepted: 30 May 2016

Published: 15 June 2016

Citation:

Arora R and Taulavuori K (2016) Increased Risk of Freeze Damage in Woody Perennials VIS-À-VIS Climate Change: Importance of Deacclimation and Dormancy Response.

Front. Environ. Sci. 4:44.

doi: 10.3389/fenvs.2016.00044
Winter survial during an annual cycle of temperate- and boreal-zone woody perennials is a multicomponent response. Two of these components are: (1) the timing, rate, and extent of cold acclimation (CA; Box 1), and (2) plants' ability to sufficiently maintain its freezing tolerance (FT) until the danger of killing frosts is passed which is determined by, among other factors, plants' ability to resist any premature/unseasonal deacclimation (DA; Box 1), which, under a predictable seasonal pattern, typically occurs during spring-warming.

\section{DA RESPONSE IS MORE CRITICAL THAN CA UNDER CLIMATE CHANGE SCENARIO}

$\mathrm{CA}$ is primarily initiated by the shortening day-length in autumn but further enhanced by cold temperatures by mid-winter. Research shows that short-days alone are sufficient to induce significant FT in woody perennials. Following are just of many examples that support this observation: (1) Pinus sylvestris acclimated to $-22^{\circ} \mathrm{C}$ under short-days alone compared to $-40^{\circ} \mathrm{C}$ under both the short-days and cold (Smit-Spinks et al., 1985), (2) Taulavuori et al. (2000) reported significant induction of FT in pine seedlings by short-days at $20^{\circ} \mathrm{C}$, and (3) Fagus sylvatica are already hardy to below $-15^{\circ} \mathrm{C}$ in October for an average year (Tranquillini and Plank, 1989). Moreover, FT of overwintering tissues in mid-winter is generally much higher than the absolute minimum temperatures typically encountered in nature (Vitasse et al., 2014). Therefore, the timing or capacity of CA does not constitute a critical factor regarding the risk of freeze-damage unless, however, an unusually early freeze in autumn causes premature leaf-loss and interferes with the preparation for maximal CA.

The dominant driver of DA, on the other hand, is warm temperature, and DA proceeds much faster (hours to days) than autumnal CA (weeks to months) (Fuchigami et al., 1982; Taulavuori et al., 2004; Kalberer et al., 2006). Consequently, erratic temperature fluctuations, i.e., "unseasonal" spring-like conditions followed by a freeze, could render partially or fully deacclimated tissues vulnerable to freeze-damage. Indeed, magnitude and frequency of such fluctuations have been on the rise in recent years (Jentsch et al., 2007; IPCC, 2014), and some of the most devastating killerfrosts across North America are attributed to such vagaries of climate, e.g., Easter freeze of 2007 (Gu et al., 2008), Mother's Day freeze of 2010, killer frost of 2012, and polar vortex of 2014. Field simulations of winter-warming events have also confirmed their damaging effects on overwintering perennials (Taulavuori et al., 1997; Bokhorst et al., 2009, 2010). We, therefore, opine that under 
a climate change scenario, the rate and extent of premature DA is a particularly critical factor determining overall winterhardiness, and a genotype/tissue with relatively greater DAresistance during "unseasonal" warm spells may be resilient to temperature extremes.

Notably, diurnal fluctuations in temperature impact FT differently than do the constant temperatures because while warm days might induce DA, cold nights could promote reacclimation (RA; Box 1), (provided DA is not totally irreversible) which could potentially serve as a "safety-net" against premature DA (Kalberer et al., 2006, 2007a,b). For example, a constant $6^{\circ} \mathrm{C}$ exposure caused steady DA of Scots pine needles whereas a temperature-cycle averaging $6^{\circ} \mathrm{C}$, i.e., $11^{\circ} \mathrm{C} / 1^{\circ} \mathrm{C}(\mathrm{D} / \mathrm{N})$, caused DA and RA whereby the colder phase resulted in reacclimation of up to $10^{\circ} \mathrm{C}$ (Leinonen et al., 1997). Such DA/RA cycling and its potential significance in wintersurvival are often ignored in studies undertaken to model winterhardiness response vis-à-vis climate change.

\section{BUD DORMANCY STATUS IMPACTS DA}

Limited research shows that DA kinetics (timing and extent) is not a single-dimension response, and regulated by factors such as, climate, genotype, and the bud dormancy status (endodormancy vs. ecodormancy; Box 2) (Ögren, 2001; Taulavuori et al., 2004; Kalberer et al., 2006; Arora and Rowland, 2011; Pagter and Arora, 2013; Ferguson et al., 2014; Vitasse et al., 2014). In endodormant (END) state, buds are relatively resistant to deacclimation whereas ecodormant (ECD) buds are "physiologically primed" for growth resumption (spring phenology) and accompanying deacclimation under conducive temperatures (Litzow and Pellett, 1980; Wolf and Cook, 1992; Kalberer et al., 2006). For example, fully cold acclimated buds of Rhododendron viscosum var. montanum deacclimated by $\sim 40 \%$ in February (chilling requirement; CR met; Box 2) when exposed to elevated temperatures but the same dose of warming in December (CR not met) resulted in only 19\% DA (Kalberer et al., 2007a).

\section{Physiology}

Physiological rationale for why plants are less prone to deacclimation in END state is not well understood. Conceivably, symplastic-isolation of shoot apices due to down-regulated cellto-cell communication (Rinne et al., 2011; Paul et al., 2014) and/or reduced content and mobility of water in END tissues (low free to bound water ratio, Fennell and Line, 2001, lower aquaporin activity/expression, Yooyongwech et al., 2008) are non-conducive for DA biochemistry, such as the loss of soluble sugars. Sugar depletion is believed to be a primary physiological explanation for DA (Ögren, 2001; Pagter and Arora, 2013). Growth regulator dynamics is also a likely factor. ABA, a growthsuppressing hormone, is widely known to accumulate in END tissues (Tanino, 2004). While bud-swell/opening is positively correlated with DA (Arora et al., 2004; Rowland et al., 2008), conditions prevailing during END are not favorable for cell expansion or bud-swell. For example, the level/perception of active GA, a hormone needed for bud burst, is lower in END tissues (Cooke et al., 2012, and references therein). ECD tissues, on the other hand, can and do deacclimate even in mid-winter if exposed to conducive warm. Such mid-winter DA is known as "passive DA" and requires ecologically unrealistic warming (Taulavuori et al., 2002) as opposed to "active DA" that occurs during spring-like conditions (Kalberer et al., 2006). Even though the temperature is typically too cold during early ECD stage to initiate ontogenetic development or deacclimation, the risk of damaging events exists and is not fixed in calendar, i.e., sudden deacclimation followed by extreme cold, absence of snow cover and hastened spring followed by nocturnal frosts (Taulavuori, 2013). Other stresses (UV, nutrient etc.) may also accelerate DA by diverting carbon allocation toward stress protection instead of cryoprotective compounds (Taulavuori et al., 2013).

\section{Chilling Requirement (CR)}

Fulfillment of $\mathrm{CR}$ is dependent on prevailing chilling temperatures during autumn. Elevated winter temperatures may result in chilling-deficit and thus delay the transition from END to ECD, especially at the southern and coastal edges of species' ranges in northern latitudes due to typically milder winters (Harrington and Gould, 2015). Indeed, atypical warming $\left(15^{\circ} \mathrm{C}\right)$ during autumn delayed END induction in birch seedlings leading to delayed budbreak next spring (Skre et al., 2008). However, such chilling-deficit is unlikely in regions currently experiencing cold winters (high elevation or latitudes). These

BOX 1 | DEFINITIONS (IN PRESENT CONTEXT):

Cold acclimation (CA): a seasonal increase in overwintering perennials' freezing tolerance during each autumn reaching the maximum by winter. Deacclimation (DA): loss of the freezing tolerance that was acquired during CA. Reacclimation (RA): Regain of some or most of the freezing tolerance (Iost during DA) when deacclimated tissues are exposed to cold acclimating conditions, e.g., cold.

\section{BOX 2 | DEFINITIONS:}

Endodormancy (END): the deepest state of dormancy in autumn during which buds must meet their chilling requirement (CR) in order to begin growth upon return of conducive environment; also called physiological dormancy, winter-dormancy or rest. Chilling requirement (CR): exposure of buds to a minimum number of chill-units (CUs) to overcome END; CUs: number of hours that buds are exposed to chilling temperatures, generally taken to be between 0 and $7^{\circ} \mathrm{C}$. Ecodormancy (ECD): inability of non-endodormant buds to grow due exclusively to non-conducive environment, such as too cold or hot, drought etc.; also called imposed dormancy or quiescence (for detailed definitions of END and ECD, readers are referred to Lang et al. (1987). Heat units (HUs): accumulated dose of conducive heat (time $\times$ temperature above a certain threshold) required by non-endodormant buds to break/grow. 
areas, on the contrary, could possibly experience even greater chilling since winter warming could convert sub-freezing temperatures with less effectiveness in fulfilling CR to slightly $>0^{\circ} \mathrm{C}$ temperatures with high chilling effectiveness, thereby, advancing the exit from END and potentially exposing tissues to spring frost damage (Hänninen, 2006). CR, a genetically determined trait with evolutionary background, varies greatly across species and ecotypes. Though exceptions occur, the northern species and ecotypes tend to have relatively low CR (Taulavuori et al., 2004, and references therein). Rationale for this may be the lack of selection pressure for evolving high $\mathrm{CR}$ in regions where winter temperatures are usually $<0^{\circ} \mathrm{C}$. These species and populations are expected to meet their CR despite warming winters, which would predispose ECD tissues to deacclimation under unseasonal warming and render vulnerable to early spring freeze. On the other hand, such liability may not be an issue in regions with cold but stable climates (Kalberer et al., 2007b). Figure 1A illustrates the responsiveness (susceptibility) of deacclimation to environmental, genetic and physiological factors over a dormancy continuum. Due to the dormancy's impact on the propensity (or lack thereof) to deacclimate, it is critically important to include dormancy-status as a key parameter in the models for predicting plants' FT vis-a-vis climate change.

\section{TEMPERATURE IMPACTS DA KINETICS}

Arguably, the extent and rate of DA depends on the total "dose" of warm temperatures, a "degree $\mathrm{x}$ duration" response, akin to classic degree-day calculations. The "threshold dose" required to induce DA in ECD tissues varies with species and regulated by genotype $\mathrm{x}$ temperature interaction. Moreover, "threshold minimum" temperature (i.e., degree) required for DA varies with species, and, in many perennials, is found to be $\sim+5^{\circ} \mathrm{C}$ (Bigras et al., 2001; Pagter et al., 2011). For example, DA rate in Vaccinium myrtillus was higher in plants kept at $+20^{\circ} \mathrm{C}$ for 10 days, compared to those kept at $+10^{\circ} \mathrm{C}$ for 24 days, and essentially no DA occurred in plants exposed to $+5^{\circ} \mathrm{C}$ up to 24 days (Taulavuori et al., 2002). Relationship between the warming duration and deacclimation rate, however, is not always linear. Whereas some plants rapidly deacclimate followed by gradually decreasing rate, others deacclimate more stably and at moderate rates for relatively longer (Kalberer et al., 2006; Pagter and Arora, 2013).

\section{PROPENSITY TO SLOW VS. FAST DA-POSSIBLE ENVIRONMENTAL OR BIOLOGICAL DRIVERS}

In light of above discussion, species better able to resist deacclimation under unseasonal warming are expected to be resilient against temperature extremes and freeze-damage. Question then arises: what environmental/biological factors might promote such a trait, and at what cost?

\section{Selection Pressure by Fluctuating Temperature Extremes and the Role of Carbohydrate Pool}

DA-resistance may possibly be a function of temperature fluctuations (frequency and magnitude) to which plants are exposed in their native habitats. Arguably, plants experiencing relatively stable temperatures may be under little evolutionary pressure to develop DA-resistance to unseasonal warming. For example, when exposed to a warming regime, azalea genotypes native to Appalachian mountains (a fluctuating temperature climate) deacclimated much slower than those from lowland, coastal regions of the northeastern U.S. (cooler and stable temperatures) which is less likely to cause sudden DA (Kalberer et al., 2007a). It may also be argued that the genotypes with greater mid-winter freezing tolerance may experience less selective pressure for resisting DA than do less-hardy ones, because the former can safely undergo significant deacclimation before becoming vulnerable to cold injury. Ecotypic differences in DA-resistance of mountain birch support this viewpoint whereby alpine ecotypes deacclimated at much faster rate than the oceanic ones (Taulavuori et al., 2004). We opine that the data on warming dose ("degree-duration") should be compared with the climatic history and plant survival of a region/provenance in question to determine if indeed genotypes exposed more frequently to DA-inducing warm-dose also tend to be slow deacclimators. Such information should be useful in "simulation studies" to provide robust parameters for modeling winterhardiness vis-à-vis climate change scenarios.

To resist DA, in spite of conducive environment, plant conceivably requires special physiology/biochemistry. Ögren (2001) proposed that an inherently higher respiration rate and therefore the sugar expenditure may explain higher temperature sensitivity of lodgepole pine to deacclimation compared to Norway spruce and Scots pine. Ögren hypothesized that while lodgepole pine (native to colder region) may rely on cold suppression of respiration in winter, those native to milder climates (Norway spruce, Scots pine) perhaps actively downregulate respiration. Such active adjustment may incur metabolic cost but a relatively larger carbohydrate reserve may favor slower deacclimation under transient warming. An accelerated deacclimation in those bilberry tissues with relatively smaller carbohydrate pool (Taulavuori et al., 1997) supports this notion. Slow deacclimators will likely also need to maintain CA associated genes (e.g., cor genes) and compounds sufficiently up-regulated despite the transient warming, which too may incur metabolic cost. Lower carbohydrate status, resulting from warmer winters, may also be mal-adaptive for any possible reacclimation. Notably, the size of carbohydrate pool will also be influenced by the weather conditions in autumn, with sunny days favoring its production and storage.

\section{Spring Phenology}

Exposure to sufficient "degree and duration" of warming (heatunits; HUs; Box 2) by ECD buds is the most important factor in regulating the timing and extent of ontogenetic development to budburst (spring phenology) (Menzel et al., 2001; Harrington 
A

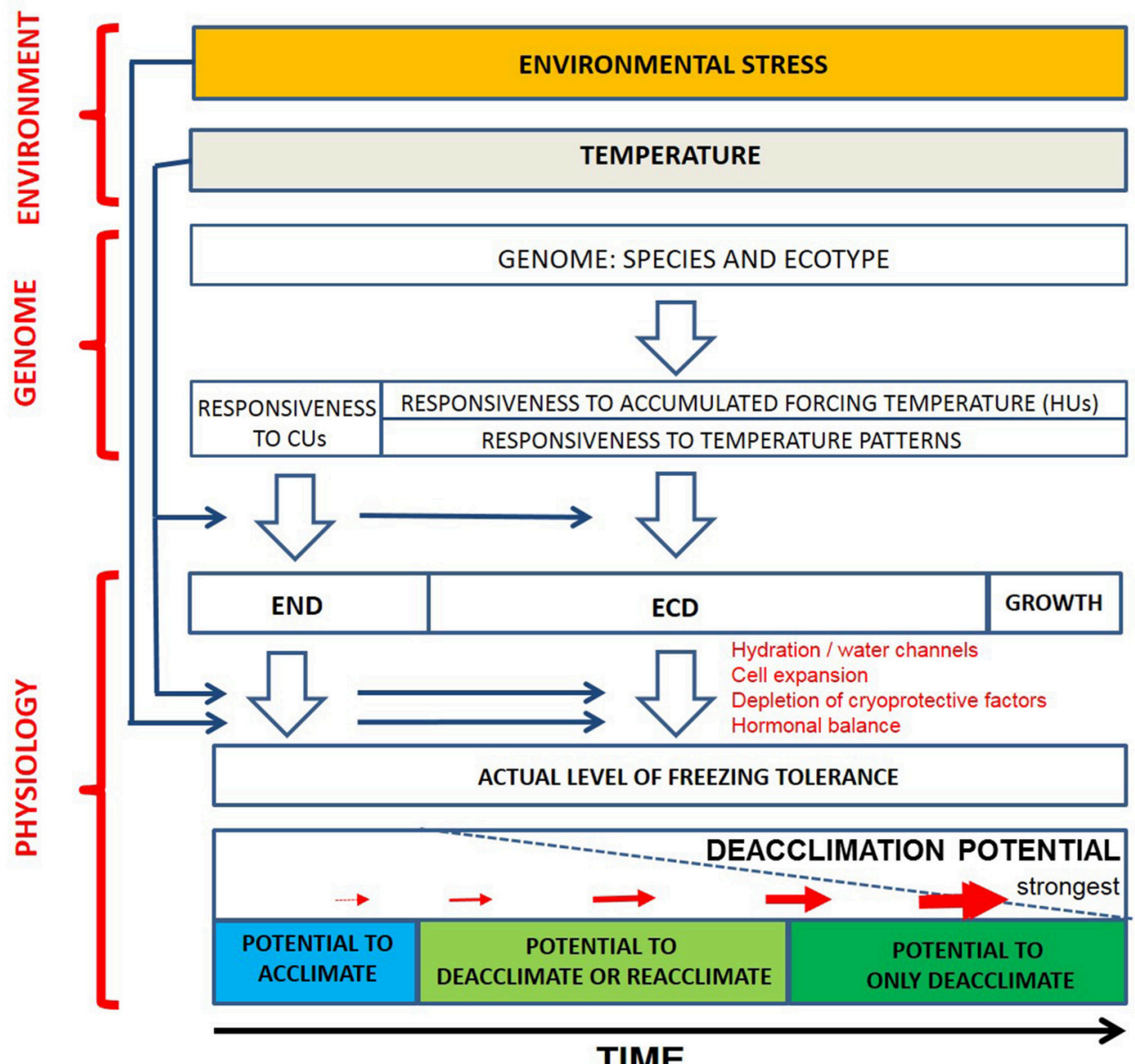

B

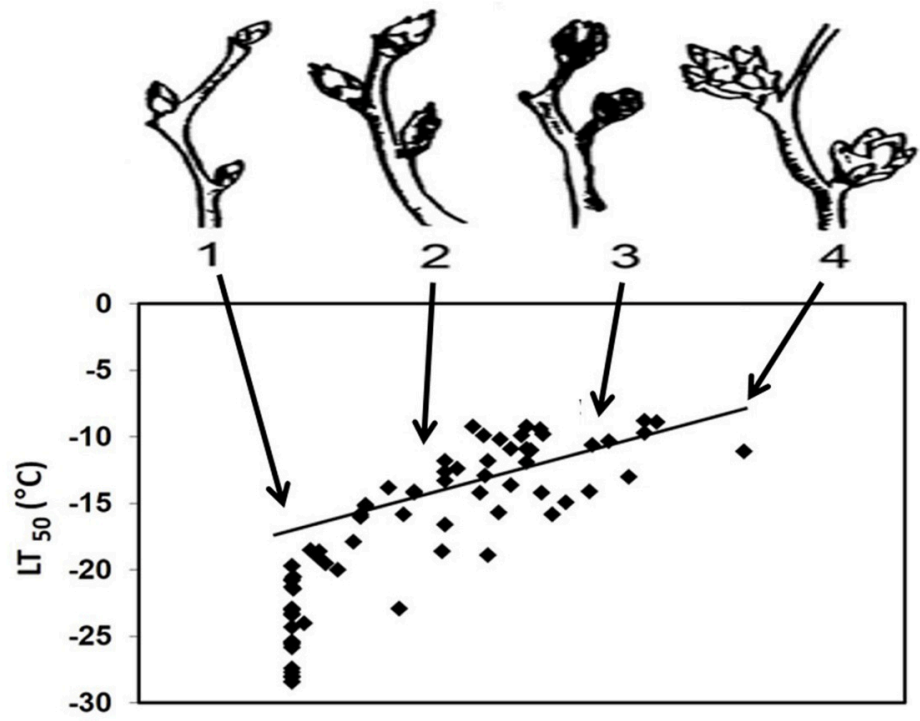

FIGURE 1 | (A). Basic concepts of plant deacclimation (DA) potential in response to interaction between environmental, genetic and physiological factors. Temperature, through genetics, determines the state of dormancy (END, ECD), and the level of freezing tolerance, which is also prone to environmental stress. Plant genome affects responsiveness to accumulating chilling units (CUs). Genotypic responsiveness to accumulating chilling units (CUs; Box 2) refers to DA resistance (strong/weak). Responsiveness to temperature patterns reflects genetic variation in DA kinetics at different times of winter. DA potential varies during the 


\section{FIGURE 1 | Continued}

dormancy continuum, with being weakest during END and progressively becoming stronger toward and during ECD due to physiological changes. Reacclimation (RA) potential exists during early ECD but decreases with accumulating HUs; (B). correlation $(r=0.84)$ between freezing tolerance and stage of opening in blueberry buds (drawn using the data extracted from Rowland et al. (2008); bud stages 1-4) 1: dormant bud with no visible sign of swelling; 2: visible bud swelling; 3: bud scales noticeably separated and flower tips becoming visible; and 4: bud scales dropped and corollas of individual flowers beginning to elongate.

et al., 2010). However, some reports have also suggested for photoperiodic control of phenology (Körner and Basler, 2010). Genetic variation exists for the HU requirement across and within species conceivably explained by the climate, latitude, altitude etc. of origin. HU requirement can also be regulated by a supposedly poorly understood relationship between chilling and HUs (Charrier et al., 2011; Polgar and Primack, 2011; Vitasse and Basler, 2013; Dantec et al., 2014) whereby HU requirement is negatively correlated to chilling accumulation (Harrington et al., 2010; Junttila and Hänninen, 2012; Laube et al., 2014). That chill- and heat-units can be satisfied by the same temperatures for some species (Cooke et al., 2012 and references therein) further adds to the complexity to this relationship.

Advance in spring phenology as a consequence of climate change/global warming has been widely reported (Peñuelas and Filella, 2001; Menzel et al., 2006; McEwan et al., 2011; $\mathrm{Fu}$ et al., 2014). It is amply evident that growth and development can lead directly or indirectly to irreversible DA (Leinonen et al., 1997; Mahfoozi et al., 2001; Rapacz, 2002a,b) and that FT is negatively correlated with bud-swell and budburst (Rowland et al., 2008; Figure 1B). Therefore, plants with somewhat delayed spring phenology, i.e., those with deeper ECD or higher HU-requirement, would be expected to better maintain FT despite the transient warming or be slow deacclimators. How does ontogenetic development modulate FT is not well understood. Conceivably, growth (cell expansion)-associated increased cellular hydration compromises FT by rendering tissues susceptible to mechanical damage from extracellular ice (Levitt, 1980) or active growth interferes with FT-maintenance by competing for energy resources (Levitt, 1980; Rapacz, 2002a,b). Growth initiation involves developmental reprogramming requiring de novo gene expression that may preclude maintenance of FT. However, it must be recognized that delayed spring phenology could shorten the growing

\section{REFERENCES}

Arora, R., and Rowland, L. J. (2011). Physiological research on winter-hardiness: deacclimation resistance, reacclimation ability, photoprotection strategies, and a cold acclimation protocol design. HortScience 46, 1070-1078. doi: 10.17660/ActaHortic.20 13.990 .6

Arora, R., Rowland, L. J., Ogden, E. L., Dhanaraj, A. L., Marian, C. O., Ehlenfeldt, M. K., et al. (2004). Rate of dehardening, stage of bud opening, and changes in dehydrin metabolism in blueberry (Vaccinium spp.) cultivars during deacclimation at constant, warm temperatures. J. Am. Soc. Hort. Sci. $129,667-674$

Bigras, J. F., Ryyppö, A., Lindstrom, A., and Stattin, E. (2001). "Cold acclimation and deacclimation of shoots and roots of conifer seedlings," in Conifer Cold season (and reduce productivity) of tree species in northern climates.

\section{CONCLUDING REMARKS}

Molecular genetic understanding of the cross-talk between loss of FT, i.e., DA, bud dormancy status, and growth/budbreak is needed in order to inform the selection of cultivars/genotypes with predictable responses to unseasonal warming episodes. A recent study by Wisniewski et al. (2015) is an important step in this direction. It is also important to include speciesspecific requirements for CR vs. HUs and both the magnitude and frequency of physiologically and regionally/locally relevant temperature fluctuations (rather than averages) in simulation experiments/modeling studies in order to infer about FT responses under a changing climate. While logistically it may be the best option available, caution should be exercised in drawing such conclusions from experiments using juvenile plants since their phenological responses may not accurately reflect the response of mature trees (Wolkovich et al., 2012; Vitasse, 2013; Lim et al., 2014).

\section{AUTHOR CONTRIBUTIONS}

Both the authors contributed to writing the manuscript which involved discussion of the themes, ideas to be projected, literature to be cited, and Figure development.

\section{ACKNOWLEDGMENTS}

We thank Dr. Mark Ehlenfeldt (USDA Fruit Lab, Chattsworth, N.J., USA) for helping with Figure 1B. We gratefully acknowledge the funding for this work from Iowa Agriculture and Home Economics Experiment Station project 3601, Iowa State University, and the Academy of Finland project no. 278364.
Hardiness, eds J. F. Bigras and S. J. Colombo (Dordrecht: Kluwer Academic Publishers), 57-88.

Bokhorst, S., Bjerke, J. W., Davey, M. P., Taulavuori, K., Taulavuori, E., Laine, K., et al. (2010). Impacts of extreme winter warming events on plant physiology in a sub-arctic heath community. Physiol. Plant. 140, 128-140. doi: 10.1111/j.13993054.2010.01386.x

Bokhorst, S., Bjerke, J. W., Tommervik, H., Callaghan, T. V., and Phoenix, G. K. (2009). Winter warming events damage sub-arctic vegetation: consistent evidence from an experimental manipulation and natural event. J. Ecol. 97, 1408-1415. doi: 10.1111/j.1365-2745.2009.01554.x

Charrier, G., Bonhomme, M., Lacointe, A., and Ameglio, A. (2011). Are budburst dates, dormancy and cold acclimation in walnut trees (Juglans regia L.) under mainly genotypic or environmental control? Int. J. Biometeorol. 55, 763-774. doi: 10.1007/s00484-011-0470-1 
Cooke, J. E., Eriksson, M. E., and Juntilla, O. (2012). The dynamic nature of bud dormancy in trees: environmental control and molecular mechanisms. Plant Cell Environ. 35, 1707-1728. doi: 10.1111/j.1365-3040.2012.02552.x

Dantec, C. F., Vitasse, Y., Bonhomme, M., Louvet, J-M., Kremer, A., and Delzon, S. (2014). Chilling and heat unit requirements for leaf unfolding in Europen beech and sesile oak populations at the southern limit of their distributions range. Int. J. Biometeorol. 58, 1853-1864. doi: 10.1007/s00484-014-0787-7

Fennell, A., and Line, M. J. (2001). Identifying differential tissue response in grape (Vitis riparia) during induction of endodormancy using nuclear magnetic resonance imaging. J. Am. Soc. Hort. Sci. 126, 681-688.

Ferguson, J. C., Moyer, M. M., Mills, L. J., Hoogenboom, G., and Keller, M. (2014). Modeling dormant bud cold hardiness and budbreak in twenty-three Vitis genotypes reveals variation by region of origin. Am. J. Enol. Vitic. 65, 59-71. doi: 10.5344/ajev.2013.13098

Fu, Y. H., Piao, S., Op de Beeck, M., Cong, N., Zhao, H., Zhang, Y., et al. (2014). Recent spring phenology shifts in western Central Europe based on mutiscale observations. Glob. Ecol. Biogeogr. 23, 1255-1263. doi: 10.1111/geb.12210

Fuchigami, L. H., Weiser, C. J., Kobayashi, K., Timmis, R., and Gusta, L. V. (1982). "A degree growth stage ( $\left.{ }^{\circ} \mathrm{GS}\right)$ model and cold acclimation in temperate woody plants," in Plant Cold Hardiness and Freezing Stress Mechanisms and Crop Implications, Vol. 2, eds P. H. Li and A. Sakai (New York, NY: Academic Press), 93-116.

Gu, L., Hanson, P. J., Post, W. M., Kaiser, D. P., Yang B., Nemani, R., et al. (2008). The 2007 eastern US spring freeze: increased cold damage in a warming world? BioScience 58, 253-262. doi: 10.1641/B580311

Hänninen, H. (2006). Climate warming and the risk of frost damage to boreal forest trees: identification of critical ecophysiological traits. Tree Physiol. 26, 889-898. doi: 10.1093/treephys/26.7.889

Harrington, C. A., and Gould, P. J. (2015). Tradeoffs between chilling and forcing in satisfying dormancy requirements for Pacific Northwest tree species. Front. Plant Sci. 6:120. doi: 10.3389/fpls.2015.00120

Harrington, C. A., Gould, P. J., and St. Clair, J. B. (2010). Modeling the effects of winter environment on dormancy release of Douglas-fir. For. Ecol. Manage. 259, 798-808. doi: 10.1016/j.foreco.2009.06.018

IPCC (2014). Impacts, Adaptation, and Vulnerability. Part A: Global and SectoralAspects. Contribution of Working Group II of the Fifth Assessment Report of theIntergovernmental Panel on Climate Change, eds C. B. Field, V. R. Barros, D. J. Dokken, K. J. Mach, M. D. Mastrandrea, T. E. Bilir, M. Chatterjee, K. L. Ebi, Y. O. Estrada, R. C. Genova, B. Girma, E. S. Kissel, A. N. Levy, S. MacCracken, P. R. Mastrandrea, and L. L. White (Cambridge; New York, NY: Cambridge Universiy Press), 1-32.

Jentsch, A., Kreyling, J., and Beierkuhnlein, C. (2007). A new generation of climatechange experiments: events, not trends. Front. Ecol. Environ. 5, 365-374. doi: 10.1890/1540-9295(2007)5[365:ANGOCE]2.0.CO;2

Junttila, O., and Hänninen, H. (2012). The minimum temperature for budburst in Betula depends on the state of dormancy. Tree Physiol. 32, 337-345. doi: 10.1093/treephys/tps010

Kalberer, S. R, Leyva-Estrada, N., Krebs, S. L., and Arora, R. (2007a). Cold hardiness of floral buds of deciduous azaleas: dehardening, rehardening, and endodormancy in late winter. J. Am. Soc. Hort. Sci. 132, 73-79.

Kalberer, S. R, Leyva-Estrada, N., Krebs, S. L., and Arora, R. (2007b). Frost dehardening and rehardening of floral buds of deciduous azaleas depend on genotypic biogeography. Environ. Exp. Bot. 59, 264-275. doi: 10.1016/j.envexpbot.2006.02.001

Kalberer, S. R., Wisniewski, M, and Arora, R. (2006). Deacclimation and reacclimation of cold-hardy plants: current understanding and emerging concepts. Plant Sci. 171, 3-16. doi: 10.1016/j.plantsci.2006.02.013

Körner, C., and Basler, D. (2010). Phenology under global warming. Science 327, 1461-462. doi: 10.1126/science.1186473

Lang, G. A., Early, J. D., Martin, G. C., and Darnell, R. L. (1987). Endo-, para-, and ecodormancy: physiological terminology and classification for dormancy research. HortScience 22, 371-377.

Laube, J., Sparks, T. H., Estrella, N., Höfler, J. F., Ankerst, D. P., and menzel, A. (2014). Chilling outweigs photoperiod in preventing precocious spring development. Glob. Change Biol. 20, 170-182. doi: 10.1111/gcb.12360

Leinonen, I., Repo, T., and Hanninen, H. (1997). Changing environmental effects on frost hardiness of scots pine during dehardening. Ann. Bot. 79, 133-138. doi: 10.1006/anbo.1996.0321
Levitt, J. (1980). Responses of Plants to Environmental Stresses, 2nd Edn, Vol. 1, New York, NY: Academic Press.

Lim, C.-C., Krebs, S. L., and Arora, R. (2014). Cold hardiness increases with age in juvenile Rhododendron populations. Front. Plant Sci. 5:542. doi: 10.3389/fpls.2014.00542

Litzow, M., and Pellett, H. (1980). Relationship of rest to dehardening in red-osier dogwood. HortScience 15, 92-93.

Mahfoozi, S., Limin, A. E., and Fowler, D. B. (2001). Developmental regulation of low-temperature tolerance in winter wheat. Ann. Bot. 87, 751-757. doi: 10.1006/anbo.2001.1403

McEwan, R. W., Brecha, R. J., Geiger, D. R., and John, G. P. (2011). Flowering phenology change and climate warming in southwestern Ohio. Plant Ecol. 212, 55-61. doi: 10.1007/s11258-010-9801-2

Menzel, A., Estrella, N., and Fabian, P. (2001). Spatial and temporal variability of the phenological seasons in Germany from 1951 to 1996. Glob. Change Biol. 7, 657-666. doi: 10.1046/j.1365-2486.2001.00430.x

Menzel, A., Sparks, T. H., Estrella, N., Koch, E., Aasa, A., Ahas, R., et al. (2006). European phenological response to climate change matches the warming pattern. Glob. Change Biol. 12, 1969-1976. doi: 10.1111/j.13652486.2006.01193.x

Ögren, E. (2001). Effects of climatic warming on cold hardiness of some northern woody plants assessed from simulation experiments. Physiol. Plantarum. 112, 71-77. doi: 10.1034/j.1399-3054.2001.1120110.x

Pagter, M., and Arora, R. (2013). Winter survival and deacclimation of perennials under warming climate: physiological perspectives. Physiol. Plant. 147, 75-87. doi: 10.1111/j.1399-3054.2012.01650.x

Pagter, M., Lefèvre, I., Arora, R., and Hausman, J.-F. (2011). Quantitative and qualitative changes in carbohydrates associated with spring deacclimation in contrasting Hydrangea species. Environ. Exp. Bot. 72, 358-367. doi: 10.1016/j.envexpbot.2011.02.019

Paul, L. K., Rinne, P. L., and van der Schoot, C. (2014). Shoot meristems of deciduous woody perennials: self organization and morphogenetic transituions. Curr. Opin. Plant Biol. 17, 86-95. doi: 10.1016/j.pbi.2013.11.009

Peñuelas, J., and Filella, I. (2001). Responses to a warming world. Science 294, 793-795. doi: 10.1126/science.1066860

Polgar, C. A., and Primack, R. B. (2011). Leaf-out phenology of temperate woody plants: from trees to ecosystems. New Phytol. 191, 926-941. doi: 10.1111/j.14698137.2011.03803.x

Rapacz, M. (2002a). Cold-deacclimation of oilseed rape (Brassica napus var. oleifera) in response to fluctuating temperatures and photoperiod. Ann. Bot. 89, 543-549. doi: 10.1093/aob/mcf090

Rapacz, M. (2002b). Regulation of frost resistance during cold de-acclimation and re-acclimation in oilseed rape. A possible role of PSII redox state. Physiol. Plant. 115, 236-243. doi: 10.1034/j.1399-3054.2002.1150209.x

Rinne, P. L. H., Welling, A., Vahala, J., Ripel, L., Ruonala, R., Kangasjarvi, J, et al. (2011). Chilling of dormant bud hyperinduces FLOWERING LOCUS T and recruits GA-inducible 1,3 beta glucanases to reopen signal conduits and release dormancy in Populus. Plant Cell 23, 130-146. doi: 10.1105/tpc.110. 081307

Rowland, L. J., Ogden, E. L., Ehlenfeldt, M. K., and Arora, R. (2008). Cold tolerance of blueberry genotypes throughout the dormant period from acclimation to deacclimation. HortScience 43, 1970-1974.

Skre, O., Taulavuori, K., Taulavuori, E., Nilsen, J., Igeland, B., and Laine, K. (2008). The importance of hardening and winter temperature for growth in mountain birch populations. Environ. Exp. Bot. 62, 254-266. doi: 10.1016/j.envexpbot.2007.09.005

Smit-Spinks, B., Swanson, B. T, and Markhart, A. H. III (1985). The effect of photoperiod and thermoperiod on cold acclimation and growth of Pinus sylvestris. Can. J. For. Res. 15, 453-460. doi: 10.1139/x85-072

Tanino, K. (2004). "The role of hormones in endodormancy induction," in Adaptations and Responses of Woody Plants to Environmental Stresses, ed R. Arora (New York, NY: Haworth Press Inc.), 157-199.

Taulavuori, K. (2013). "Vegetation at high latitudes under global warming," in Causes, Impacts and Solutions to Global Warming, eds I. Ibrahim, C. O. Dincer, Colpan, and F. Kadioglu (New York, NY: Springer), 3-16.

Taulavuori, K., Laine, K., and Taulavuori, E. (2013). A review: experimental studies on Vaccinium species in relation to air pollution and global change. Environ. Exp. Bot. 87, 191-196. doi: 10.1016/j.envexpbot.2012.10.002 
Taulavuori, K., Laine, K., Taulavuori, E., Pakonen, T., and Saari, E. (1997). Accelerated dehardening in the bilberry (Vaccinium myrtillus L.) induced by a small elevation in air temperature. Environ. Pollut. 98, 91-95. doi: 10.1016/S0269-7491(97)00115-2

Taulavuori, K., Taulavuori, E., and Laine, K. (2002). Artificial deacclimation response of Vaccinium myrtillus (L.) in mid-winter. Ann. Bot. Fenn. 39, 143-147.

Taulavuori, K., Taulavuori, E., Sarjala, T., Savonen, E.-M., Pietiläinen, P., Lähdesmäki, P., et al. (2000). In vivo chlorophyll fluorescence is not always a good indicator of cold hardiness. J. Plant Physiol. 157, 227-229. doi: 10.1016/S0176-1617(00)80195-9

Taulavuori, K., Taulavuori, E., Skre, O., Nilsen, J., Igeland, B., and Laine, K. (2004). Dehardening of mountain birch (Betula pubescens ssp. czerepanovii) ecotypes at elevated winter temperatures. New Phytol. 162, 427-436. doi: 10.1111/j.14698137.2004.01042.x

Tranquillini, W., and Plank, A. (1989). Ökophysiologische untersuchungen an rotbuchen (Fagus sylvatica L.) in verschiedenen Höhenlagen Nord- und Südtirols. Cent. Gesamte Forstwes. 3, 225-246.

Vitasse, Y. (2013). Ontogenetic changes rather than difference in temperature cause understory trees to leaf out earlier. New Phytol. 198, 149-155. doi: 10.1111/nph.12130

Vitasse, Y., and Basler, D. (2013). What role for photoperiod in the bud burstphenology of European beech. J. For. Res. 132, 1-8. doi: 10.1007/s10342012-0661-2

Vitasse, Y., Lenz, A., and Körner, C. (2014). The interaction between freezing tolerance and phenology in temperate deciduous trees. Front. Plant Sci. 5:541. doi: 10.3389/fpls.2014.00541
Wisniewski, M., Norelli, J., and Artlip, T. (2015). Overexpression of a peach $\mathrm{CBF}$ gene in apple: a model for understanding the integration of growth, dormancy, and cold hardiness in woody plants. Front. Plant Sci. 6:85. doi: 10.3389/fpls.2015.00085

Wolf, T. K., and Cook, M. K. (1992). Seasonal deacclimation patterns of three grape cultivars at constant, warm temperature. Am. J. Enol. Viticult. 43, 171-179.

Wolkovich, E. M., Cook, B. I., Allen, J. M., Crimmins, T. M., Betancourt, J. L., Travers, S. E., et al. (2012). Warming experiments underpredict plant phenological responses to climate change. Nature 485, 494-497. doi: 10.1038/nature 11014

Yooyongwech, S., Horigane, A. K., Yoshida, M., Yamaguchi, M., Sekozawa, Y., Sugaya, S., et al. (2008). Changes in aquaporin gene expression and magnetic resonance imaging of water status in peach tree flower buds during dormancy. Physiol. Plant. 134, 522-533. doi: 10.1111/j.1399-3054.2008.01143.x

Conflict of Interest Statement: The authors declare that the research was conducted in the absence of any commercial or financial relationships that could be construed as a potential conflict of interest.

Copyright (c) 2016 Arora and Taulavuori. This is an open-access article distributed under the terms of the Creative Commons Attribution License (CC BY). The use, distribution or reproduction in other forums is permitted, provided the original author(s) or licensor are credited and that the original publication in this journal is cited, in accordance with accepted academic practice. No use, distribution or reproduction is permitted which does not comply with these terms. 